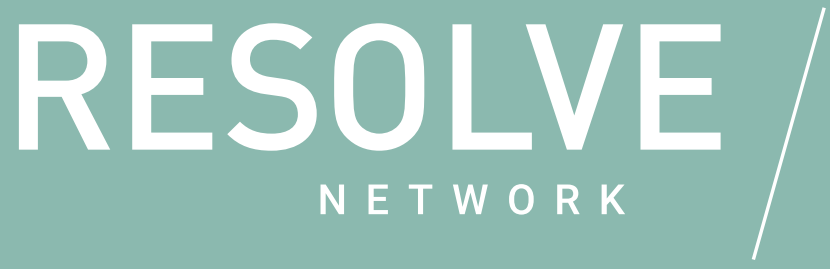

\title{
LINKING OFFICIAL AND UNOFFICIAL APPROACHES \\ OF ENGAGING ARMED ACTORS
}

\author{
CLAUDIA HOFMANN
}

\section{COMMUNITY-BASED ARMED GROUPS SERIES}

\section{${ }^{66}$ Conflicts in which one or more of the main actors are not part of the state demonstrate the limitations of engagement in a state-centric system.}

\section{FAST FACTS}

$\rightarrow$ By using their dependence on a positive public image, NGOs and private actors have been able to persuade some armed actors to change their behavior.

$\rightarrow$ Coordinated approaches between different actors utilizing their respective strengths may help achieve specific goals and sustainable resolutions where non-state armed actors are involved.

$\rightarrow$ Strategically linking official and unofficial approaches may avoid adverse consequences and provide beneficial and constructive approaches to engaging non-state armed actors now and in the

\section{Context}

Internal conflict ${ }^{1}$ - conflict between a government and a non-governmental party, such as non-state armed actors or community-based armed groups-remains the most common type of conflict today. ${ }^{2}$ In 2015, the number of internal conflicts rose to over 50 and have since remained at that level, vastly outnumbering the two interstate conflicts recorded most recently

1 Mary Kaldor, New and Old Wars: Organised Violence in a Global Era (Cambridge, Polity, 2013).

2 Definition of "intrastate conflict:" "A conflict between a government and a non-governmental party, with no interference from other countries." Numbers include those for "internationalized conflict:" "armed conflict between a government and a nongovernment party where the government side, the opposing side, or both sides, receive troop support from other governments that actively participate in the conflict." See "Definitions," Uppsala Conflict Data Program (UCDP), accessed March 27, 2020, https:// www.pcr.uu.se/research/ucdp/definitions/. 
in 2018. ${ }^{3}$ These type of conflicts, occurring within states rather than between them, as well as the involvement of non-state armed actors within them, pose fundamental challenges to the traditional conflict resolution approaches of state actors and international organizations. Conflicts in which one or more of the main actors are not part of the state demonstrate the limitations of engagement in a state-centric system.

From counterinsurgency and containment, through negotiation and mediation, to integration and cooptation, ${ }^{4}$ state and international approaches to address non-state armed actors face a significant obstacle: legitimacy. On the one hand, there is a need to engage armed actors to meaningfully address the conflict. On the other, the assumed illegitimacy of non-state armed actors and community-based armed groups' activities means that there are implications for seeming to accept their grievances as legitimate through such engagement. The appearance of the latter could adversely affect the traditional strategic position of international and state actors with regard to their negotiation position and conflict resolution efforts as well as their status as governing power through their monopoly of the legitimate use of physical force and undermine the effectiveness of their approaches.

In the face of this dichotomy, official, state-based actors, specialized non-governmental organizations (NGOs), and private actors-including elder statesmen, influential international figures, and retired high political officials-have developed independent conflict resolution approaches, leveraging their non-state status to fill the gap left by states and international organizations. These unofficial, approaches are mainly centered around:

- 1) promoting international norms among non-state armed actors with the goal of persuading armed actors to change their behavior, particularly in favor of the protection of civilians and combatants; and

- 2) engaging in dialogue, mediation, mediation support, and negotiation with the goal to resolve the conflict itself. ${ }^{5}$

In practice, states, international organizations, and these specialized NGOs and private actors frequently operate in the same locations at the same time, yet independently from each other. In the past, this led to unintended consequences that undermined the effectiveness of their respective approaches, such as duplication of effort and the instrumentalization of their efforts. To avoid such adverse effects while leveraging their respective strengths in engaging non-state armed actors and state-based actors, these diverse actors alike need to improve communication, coordination, collaboration, and cooperation.

3 Most recent data from 2018. See "Armed Conflict by Type," Uppsala Conflict Data Program (UCDP), accessed March 27, 2020, https://ucdp.uu.se/downloads/charts/.

4 Véronique Dudouet, "Mediating Peace with Proscribed Armed Groups," United States Institute of Peace, Special Report no. 239, 2010; Claudia Hofmann, “Engaging Non-State Armed Groups in Humanitarian Action," International Peacekeeping 13(3) (2006): 396-409; Claudia Hofmann and Ulrich Schneckener, "NGOs and Nonstate Armed Actors. Improving Compliance with International Norms," United States Institute of Peace, Special Report no. 284, 2011.

5 NGOs, particularly in the development field, have also demonstrated constructive engagement with non-state armed actors in facilitating the delivery of humanitarian assistance in territory controlled by armed actors. Such action rarely moves beyond short- and medium-term practical considerations. See Jörn Grävingholt, Claudia Hofmann, and Stephan Klingebiel, Development Cooperation and Non-State Armed Groups, Bonn: German Development Institute (DIE) (Studies 29), 2007, chapters 4 and 5 . 


\section{Relevance to Policy and Practice}

In many cases, specialized NGOs and private actors have attempted to leverage contacts and access from their existing or previous work to facilitate dialogue with non-state armed actors, conduct informal pre-negotiations, prepare non-papers, and mediate directly between non-state armed actors and host governments. The goal of these unofficial efforts is to mitigate armed actor violence, especially when committed against civilian populations. ${ }^{6}$ Despite considerable limitations, these approaches have offered constructive new avenues for engaging non-state armed actors that can, in some instances, offset the challenges state-based actors encounter. ${ }^{7}$ Policymakers can involve such approaches in their official or unofficial efforts of conflict resolution or stabilization to improve their overall effectiveness, reach, and sustainability.

For example, NGOs and private actors have been successful in leveraging the claims of moral authority, popular representation, and governance of armed actors that promote a political agenda and program - such as traditional rebel groups or clan chiefs-as sources of legitimacy. By using their dependence on a positive public image, NGOs and private actors have been able to persuade some armed actors to change their behavior. This mechanism can also be effective for community-based armed groups that claim responsibility towards a constituency or stakeholders.

For instance, Geneva Call, a Swiss NGO, has persuaded over 50 armed actors to unilaterally sign their "Deed of Commitment". The Deed commits signatories to adhering to a total ban on antipersonnel mines, undertaking stockpile destruction, allowing monitoring and evaluation of these efforts, adjusting internal orders and directives in accordance with the Deed, and treating this commitment as part of a broader commitment to humanitarian norms. ${ }^{8}$ Incentives for signatories to promote stockpile reduction among their constituencies can range from the provision of training in international humanitarian law and the prestige of engaging with a Swiss organization. In 2018, 52 signatories were actively engaged with Geneva Call in awareness-raising and training sessions, 16 groups were engaged in strengthening their internal rules and procedures, and 2,500 stockpiled anti-personnel mines were destroyed by the Polisario Front in coordination with the Sahrawi Mine Action Coordination Office in the Western Sahara. ${ }^{9}$

The Carter Center - a U.S.-based NGO headed by elder statesman, Nobel Peace Prize laureate, and former U.S. President Jimmy Carter-for example, offers high-level mediation services to both non-state armed actors and states. The approach builds on existing relationships and the rationale that constructive dialogue will eventually lead to a reduction of violence. For instance, the Carter Center successfully negotiated a six months ceasefire between Colonel Omar al-

6 Claudia Hofmann, Reasoning with Rebels. International NGOs' Approaches to Engaging Armed Groups, RP 11, Berlin: German Institute for International and Security Affairs, 2012.

7 Claudia Hofmann, "Engaging Armed Actors in Conflict Mediation. Consolidating Government and Non-government Approaches," in Humanitarian Engagement with Non-state Armed Groups (London: Chatham House, 2016), 23-37.

8 "Deed of Commitment Under Geneva Call for Adherence to a Total Ban on Anti-Personnel Mines and for Cooperation in Mine Action," Geneva Call, accessed March 27, 2020, https://www.genevacall.org/wp-content/uploads/2019/07/DoC-Banning-anti-personnel-mines.pdf. The impact of individual measures on levels of violence is difficult to establish but Geneva Call conducts long-term monitoring and evaluation missions for each signatory where possible.

9 “Annual Report 2018," Geneva Call, accessed March 27, 2020, https://www.genevacall.org/wp-content/uploads/2019/07/ GEC-RA2018A4 web-compressed-1.pdf, 12. 
Bashir and the Sudan People's Liberation Army/Movement (SPLA/M) and assisted in achieving mutual commitments by Bashir and Yoweri Museveni of Uganda in the Nairobi Agreement in 1999. ${ }^{10}$ Similarly, the Carter Center has engaged in conflict resolution efforts between Israel and the Occupied Palestinian Territory, resulting in constructive impact on the 2008 Israel-Hamas ceasefire, the release of Israeli soldier Gilad Shalit in October 2011, and the May 2011 FatahHamas agreement. ${ }^{11}$

Initiatives such as these broaden the range of engagement and conflict resolution approaches with non-state armed groups as well as community-based armed groups available to international actors and should be taken into consideration more strategically. Instead of focusing solely on "track 1" or even "track 1.5" approaches, policymakers should consider more careful coordination and support for "track 2" and "track 3" engagement. ${ }^{12}$ Coordinated approaches between different actors utilizing their respective strengths may help achieve specific goals and sustainable resolutions where non-state armed actors are involved.

\section{Recommendations}

The nature of NGOs and private actors allows them to engage non-state armed actors from a different vantage point than state actors. They portray their work as independent from strategic and financial considerations and they lack the resources to coerce armed actors into an agreement. Accordingly, in the field, NGOs and private actors can be perceived as more principled, altruistic, and committed to a sustainable resolution than more political state actors. As a result, some armed actors have been more open to engaging constructively with NGOs and private actors for conflict resolution or violence reduction.

At the same time, NGOs and private actors face a number of challenges in this work that state actors and international organizations should take into account when considering a collaboration. Often, limited financial resources present NGOs and private actors with an obstacle to continued and committed engagement over a longer period, leading to serious questions about the sustainability and feasibility of their efforts. Additionally, the mandate, credibility, and legitimacy of unofficial actors are not as clear-cut as that of official actors, such as states and international organizations. Accordingly, collaboration between a state actor or international organization and an NGO or private actor should be clearly outlined, defined, and in line with the official policy it would complement.

10 Hofmann, Reasoning with Rebels. The Carter Center reduced their conflict resolution involvement in Sudan after the Intergovernmental Authority on Development (IGAD) established itself as a strong mediator after 2002. The Center remains active with government officials, opposition leaders, and civil society members in Sudan and South Sudan to present. See "Sudan," Carter Center, accessed March 27, 2020, https://www.cartercenter.org/countries/sudan.html.

11 Claudia Hofmann and Carolin Goerzig, "Influencing Negotiation Willingness in the Middle East: The Potential Contributions of Private Actors," Negotiation Journal 32 (2) (2016): 151-163. See also "Supporting Peace in Israel and the Occupied Palestinian Territory," Carter Center, accessed March 27, 2020, https://www.cartercenter.org/peace/conflict resolution/israel-palestine/ index.html.

12 Palmiano Federer, Julia, Julia Pickhardt, Philipp Lustenberger, Christian Altpeter, and Katrina Abatis, "Beyond the Tracks? Reflections on Multitrack Approaches to Peace Processes," Centre for Humanitarian Dialogue, the Center for Security Studies ETH Zurich, Folke Bernadotte Academy and swisspeace, accessed May 27, 2020, https://css.ethz.ch/content/dam/ethz/ special-interest/gess/cis/center-for-securities-studies/pdfs/Mediation-Multi-Track-01-block.pdf. 
The plurality of simultaneous unofficial initiatives has also led to duplication of effort and instrumentalization in the past. ${ }^{13}$ Programs that underdeliver their potential can present security issues for international personnel and local staff, for example if a particular effort is no longer appreciated by the armed actor. This could affect related efforts of state actors and international organizations. Finally, measuring the longer-term effectiveness and sustainability of unofficial engagement by NGOs and private actors has been almost impossible and often lacking in effective monitoring and evaluation as access and resources wane when funding changes.

Nonetheless, the contributions of specialized NGOs and private actors are worth considering in three particular fields: i) supplementing official policy; ii) taking on responsibility for distinct policy components; and iii) developing policy and early warning.

\section{Supplementing Official Policy}

NGOs, private actors, states, and international organizations do not work independently from each other. Not only are they active in the same fields, especially in development assistance and humanitarian aid, NGOs and private actors can also receive funding for many of their initiatives from states and international organizations. Additionally, NGOs and private actors often provide specialized expertise to states and international organizations through consultations that may impact official policy. To date, the collaboration between NGOs and private actors and states and international organizations primarily remains ad hoc and focused on development and humanitarian aid. ${ }^{14}$

$\rightarrow$ States and international organizations should increase their engagement with specialized NGOs and private actors' expertise through regular cross-sectoral consultations and exchanges, specifically in the context of engagement with non-state armed actors and community-based armed groups.

Regular and systematic exchanges with officials that have the ability to influence decisionmaking on armed actor engagement could improve official policy and coordination between unofficial and official actors. An example of such regular exchange and consultation is the Oslo Forum, a series of retreats for international conflict mediators, high-level decision-makers, and other peace process actors. ${ }^{15}$

$\rightarrow$ States and international organizations should engage with and learn from the diverse vantage points that NGOs and private actors can bring to official processes.

Specialized NGOs and private actors may be able to supplement an official initiative with non-state to non-state mediation services and mediation support. As an example, the Centre for Humanitarian Dialogue (HD), a Swiss NGO, provides ongoing support to the Norwegian government in their facilitation of the conflict between the government of the Philippines and the communist National Democratic Front. The HD Centre oversees the work of the Joint Monitoring Committee responsible for receiving and processing complaints of violations of the

13 Anderson, Mary, Do No Harm: How Aid Can Support Peace-Or War (Boulder, Lynne Rienner, 1999).

14 Hofmann, "Engaging Armed Actors in Conflict Mediation," 30.

15 "The Oslo Forum," Centre for Humanitarian Dialogue, accessed May 4, 2020, https://www.hdcentre.org/osloforum/ the-oslo-forum/. 
Comprehensive Agreement on the Respect for Human Rights and International Humanitarian Law. ${ }^{16}$ In spaces where community-based armed groups are active, specialized NGOs and private actors can facilitate their official or unofficial engagement in national mediation and reconciliation processes to support a holistic process.

\section{Taking Responsibility for Distinct Policy Components}

States and international organizations continue to experience challenges in engaging nonstate armed actors related to the sovereignty, legitimacy, and authority of armed actors, and the credibility of their grievances. Many are hesitant to involve NGOs and private actors more strategically because of potential uncertainty and unintended political consequences of engaging armed groups even through a secondary organization. However, specialized NGOs and private actors may be in a position to step into that space and circumvent broader issues of legitimacy.

$\rightarrow$ States and international organizations should support specialized NGOs and private actors to engage armed actors on specific issues through strategic partnerships.

Specific policy components that require cooperation from non-state armed actors and community-based armed groups to be addressed comprehensively could be covered by strategic partnerships with NGOs and private actors. As an example, in its effort to comprehensively address the elimination of the use of anti-personnel landmines and other explosive remnants of war, the Swiss government entered strategic partnerships with Geneva Call, the Geneva International Center for Humanitarian Demining (GICHD), the Cluster Munition Coalition, and the Landmine and Cluster Munition Monitor. ${ }^{17}$ Geneva Call, for its part, engages armed actors to persuade them to unilaterally commit to banning anti-personnel landmines and to destroying any landmine stockpile. This strategy allows the Swiss government to comprehensively approach their mine action policy, without grappling with issues related to sovereignty, legitimacy, authority, and credibility. The International Committee of the Red Cross utilizes a similar approach of persuasion with non-state armed actors in the field of international humanitarian and human rights law. ${ }^{18}$

\section{Developing Policies and Providing Early Warning}

States and international organizations working on development policy and humanitarian aid employ traditional bureaucracies that rely on established reporting and response systems. While these systems tend to be reliable, they often fail to capture nuanced developments on the ground and can be slow in addressing new ones. Specialized NGOs and private actors' existing proximity

16 "Philippines NDF," Centre for Humanitarian Dialogue, accessed March 27, 2020, https://www.hdcentre.org/activities/ philippines-ndf/.

17 "Anti-personnel mines, cluster munitions and other explosive remnants of war," Swiss Federal Department of Foreign Affairs, accessed March 27, 2020, https://www.eda.admin.ch/eda/en/home/foreign-policy/security-policy/disarmament-non-proliferation/conventional-weapons/mines.html. The Swiss government also works closely with the International Committee of the Red Cross (ICRC).

18 Claudia Hofmann and Ulrich Schneckener, "The Power of Persuasion. The Role of INGOs in Engaging Armed Groups", in Inducing Compliance with International Humanitarian Law, ed. Heike Krieger (Cambridge: Cambridge University Press, 2015), 79-111. The International Committee of the Red Cross is more accurately classified as an independent quasi-governmental organization. 
to armed actors and community-based armed groups may allow for faster detection and shorter reaction times.

$\rightarrow$ States and international organizations should engage specialized NGOs and private actors' indepth knowledge of situations on the ground.

Their proximity in the field and their personal connections often provide NGOs and private actors with insight into the development of situations in the field. NGOs and private actors may be able to identify windows of opportunity and potential for decline in a situation and provide early warning of imminent risks. An example is the Carter Center's work in Uganda, which seized a window of opportunity and access before an official process through the Northern Uganda Peace Initiative (NUPI) and supported by USAID was established in 2003. Regular cross-sectoral consultations and exchanges between state actors, international organizations, and NGOs and private actors active in the respective field would facilitate the identification of such opportunities.

$\rightarrow$ States and international organizations should engage with NGOs and private actors who are already on the ground to act more promptly in a window of opportunity.

NGOs and private actors tend to be more flexible and nimbler in their actions, allowing them to take initial steps towards instituting a constructive dialogue with non-state armed actors and community-based armed groups before states and international organizations are able. Support from states or international organizations could also alleviate concerns regarding lack of resources and appropriate training in negotiation and mediation, situational awareness, and recommended security measures. Seizing immediately on an opportunity may open the door for higher-level talks later on. As an example, the facilitation by Geneva Call between the United Somali Congress/Somali National Alliance and the African Union in 2007 regarding the destruction of land mine stockpiles served as a trust-building measure that benefited the combatant parties in their following interactions.

\section{Conclusion}

Many intervening external actors-official and unofficial-are involved in engaging non-state armed actors. These external actors employ different approaches, follow different goals, prioritize different instruments, provide different perspectives, and may even compete with each other in terms of goals, funding, and recognition. The lack of coordination between these approaches may not only fail to optimize engagement and maximize outcomes, but it may also lead to unintended, adverse consequences. Strategically linking official and unofficial approaches may avoid such adverse consequences and provide beneficial and constructive approaches to engaging non-state armed actors now and in the future. 


\section{Suggested Further Reading}

\section{On Contemporary Conflict}

Call, Charles T. "The Fallacy of the 'Failed State'." Third World Quarterly 29, no. 8 (2008): 1491-1507.

Kaldor, Mary. "In Defence of New Wars." Stability: International Journal of Security and Development 2, no. 1, p.Art. 4 (2013).

Rotberg, Robert I., ed. State Failure and State Weakness in a Time of Terror. Washington, DC: Brookings Institution Press, 2003.

\section{On Armed Actors and Small Arms Control}

de Tessières, Savannah. "Unit 10: Supporting the Development of Armed Actor Capacity for Weapons and Ammunition Management." In Effective Weapons and Ammunition Management in a Changing DDR Context: A Handbook for Practitioners, 44-49. UNODA and UNDPKO, 2018. https://peacekeeping. un.org/sites/default/files/effective weapons and ammunition management ddr handbook.pdf.

Florquin, Nicolas, Pascal Bongard, and Emilia Richard. "Options for Engagement: Armed Groups and Humanitarian Norms." In Small Arms Survey 2010: Gangs, Groups and Guns, 304-33. Cambridge: Cambridge University Press, 2010. http://www.smallarmssurvey.org/fileadmin/docs/A-Yearbook/2010/en/ Small-Arms-Survey-2010-Chapter-12-EN.pdf.

\section{On Creating Negotiation Momentum}

Hofmann, Claudia and Carolin Goerzig. "Influencing Negotiation Willingness in the Middle East: The Potential Contributions of Private Actors." Negotiation Journal 32, no. 2 (2016): 151-163.

Planta, Katrin and Véronique Dudouet. Fit for Negotiation? Options and Risks in the Political Transformation of Non-conventional Armed Groups. Oslo: Norwegian Peacebuilding Resource Centre (NOREF), 2015. https://www.clingendael.org/sites/default/files/pdfs/Planta Dodouet NOREF Fit\%20for\%20 negotiation Feb\%202015 final version.pdf.

\section{On Persuasion Strategies for Engagement}

Goerzig, Carolin und Claudia Hofmann. "The Hurting Way Out: Group Cohesion and the Mitigating Potential of Private Actors in Conflict Negotiation." Max Planck Institute for Social Anthropology Working Papers No. 177 (2016). https://www.eth.mpg.de/pubs/wps/pdf/mpi-eth-working-paper-0177.

Kaplan, Oliver. "Nudging Armed Groups: How Civilians Transmit Norms of Protection." Stability: International Journal of Security \& Development 2, no. 3, p.Art. 62 (2013). 


\section{Sources}

Anderson, Mary. Do No Harm: How Aid Can Support Peace-Or War. Boulder: Lynne Rienner, 1999.

Carter Center. "Sudan." Accessed March 27, 2020. https://www.cartercenter.org/countries/sudan.html.

Carter Center. "Supporting Peace in Israel and the Occupied Palestinian Territory." Accessed March 27, 2020. https://www.cartercenter.org/peace/conflict resolution/israel-palestine/index.html.

Center for Humanitarian Dialogue. "Philippines NDF." Accessed March 27, 2020. https://www.hdcentre. org/activities/philippines-ndf/.

Center for Humanitarian Dialogue. "The Oslo Forum." Accessed May 4, 2020. https://www.hdcentre.org/ osloforum/the-oslo-forum/.

Dudouet, Véronique. "Mediating Peace with Proscribed Armed Groups." United States Institute of Peace, Special Report no. 239, 2010.

Geneva Call. "Annual Report 2018." Accessed March 27, 2020. https://www.genevacall.org/wp-content/ uploads/2019/07/GEC-RA2018A4 web-compressed-1.pdf.

Geneva Call. "Deed of Commitment Under Geneva Call for Adherence to a Total Ban on Anti-Personnel Mines and for Cooperation in Mine Action." Accessed March 27, 2020. https://www.genevacall.org/ wp-content/uploads/2019/07/DoC-Banning-anti-personnel-mines.pdf.

Grävingholt, Jörn, Claudia Hofmann, and Stephan Klingebiel. Development Cooperation and Non-State Armed Groups. Bonn: German Development Institute (DIE) (Studies 29), 2007.

Hofmann, Claudia. "Engaging Armed Actors in Conflict Mediation. Consolidating Government and Nongovernment Approaches." In Humanitarian Engagement with Non-state Armed Groups, 23-37. London: Chatham House, 2016.

Hofmann, Claudia. "Engaging Non-State Armed Groups in Humanitarian Action."I nternational Peacekeeping 13(3) (2006): 396-409.

Hofmann, Claudia. Reasoning with Rebels. International NGOs 'Approaches to Engaging Armed Groups. RP 11. Berlin: German Institute for International and Security Affairs, 2012.

Hofmann, Claudia and Carolin Goerzig. "Influencing Negotiation Willingness in the Middle East: The Potential Contributions of Private Actors." In Negotiation Journal 32 (2) (2016): 151-163.

Hofmann, Claudia and Ulrich Schneckener. "NGOs and Nonstate Armed Actors. Improving Compliance with International Norms." USIP Special Report no. 284, 2011.

Hofmann, Claudia and Ulrich Schneckener. "The Power of Persuasion. The Role of INGOs in Engaging Armed Groups." In Inducing Compliance with International Humanitarian Law, edited by Heike Krieger, 79-111. Cambridge: Cambridge University Press, 2015.

Kaldor, Mary. New and Old Wars: Organised Violence in a Global Era. Cambridge: Polity, 2013.

Palmiano Federer, Julia, Julia Pickhardt, Philipp Lustenberger, Christian Altpeter, and Katrina Abatis. "Beyond the Tracks? Reflections on Multitrack Approaches to Peace Processes." Centre for Humanitarian Dialogue, Center for Security Studies ETH Zurich, Folke Bernadotte Academy and swisspeace. Accessed 
May 27, 2020. https://css.ethz.ch/content/dam/ethz/special-interest/gess/cis/center-for-securitiesstudies/pdfs/Mediation-Multi-Track-01-block.pdf.

Swiss Federal Department of Foreign Affairs. "Anti-personnel mines, cluster munitions and other explosive remnants of war." Accessed March 27, 2020. https://www.eda.admin.ch/eda/en/home/foreign-policy/security-policy/disarmament-non-proliferation/conventional-weapons/mines.html.

Uppsala Conflict Data Program (UCDP). "Armed Conflict by Type." Accessed March 27, 2020. https://ucdp. uu.se/downloads/charts/.

Uppsala Conflict Data Program (UCDP). “Definitions." Accessed March 27, 2020. https://www.pcr.uu.se/ research/ucdp/definitions/. 


\section{About the Note}

Author: Dr. Claudia Hofmann

Dr Claudia Hofmann specializes in the role of non-state actors in world politics, with a particular emphasis on rebels, insurgents, and organized criminal groups as a challenge to foreign and security policy. Her most recent research focuses on creating negotiation willingness and momentum, and the effects of levels of non-state armed group cohesion on conflict negotiation.

Dr Hofmann has a rich background in academic teaching and policy-oriented in-depth research on both sides of the Atlantic. Her work has resulted in numerous peer-reviewed academic publications, international policy papers, presentations, and policy consultations.

Dr Claudia Hofmann is the Director of the Executive Master in International Service (MIS) program at the School of International Service at American University in Washington, DC. She is also an Associate Fellow at the Royal Institute of International Affairs, Chatham House.

The views expressed in this publication are those of the author. They do not necessarily reflect the views of the RESOLVE Network, the U.S. Institute of Peace, or any entity of the U.S. government.

\section{RESOLVE NETWORK}

better research.informed practice.improved policy on violent extremism. www.resolvenet.org

\section{$\square$ ( ) in}
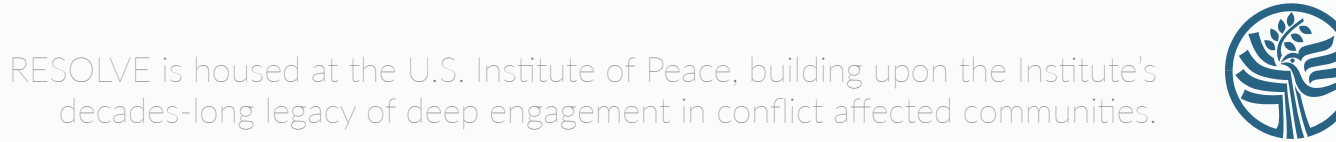
United States Institute of Peace Making Peace Possible 